\title{
INOVASI SISTEM PEMBELAJARAN PADA MASA PANDEMI COVID-19 (SUATU STUDI DESKRIPTIF KUALITATIF DI SMAN 1 EMPANG)
}

\author{
Sutono', Dr. Kahar Karim², Aka Kurnia SF.S.Ag.M.Sn³ \\ 1,2Sekolah Pascasarjana Manajemen Inovasi Universitas Teknologi Sumbawa \\ 3 Fakultas Ilmu Komunikasi Universitas Teknologi Sumbawa \\ ${ }^{*}$ Corresponding Author email: aka.kurnia@uts.ac.id
}

\begin{abstract}
Abstrak
Diterima :

Penelitian ini bertujuan untuk memenuhi kebutuhan sistem pembelajaran yang efektif dan Bulan Januari 2021 efisien di tengah pandemi Covid-19. Sebagaimana diketahui, Coronavirus Disease 2019 atau Covid-19 merupakan virus jenis baru yang mengganggu sistem pernafasan, pneumonia akut, hingga menyebabkan kematian. Adanya kekhawatiran atas besarnya resiko yang ditimbulkan tersebut berpengaruh pada sektor pendidikan, yaitu dengan hadirnya inovasi pendidikan berbasis teknologi digital, yang mengganti segala bentuk kegiatan di sekolah dilakukan secara daring (online). Meskipun bertujuan untuk

Diterbitkan : Bulan Februari memenuhi dan memudahkan proses pembelajaran dari rumah, justru pada penerapannya 2021 masih menimbulkan beberapa masalah, khususnya tidak efektif dan efisiennya kegiatan pembelajaran. Penelitian ini menggunakan metode deskriptif dengan pendekatan kualitatif, di mana yang dikumpulkan berupa pendapat, informasi bukan angka, konsepkonsep dan keterangan yang berbentuk uraian untuk mendeskripsikan dan meginterpretasikan suatu objek dengan apa adanya. Hasil penelitian menunjukkan bahwa,

Keyword : salah satu pengaruh pandemik Covid-19 terhadap bidang pendidikan di SMAN 1 Empang mangrove, kepadatan, kepiting, rehabilitasi adalah diambil beberapa kebijakan berupa menonaktifkan kegiatan di sekolah dan memberlakuan pembelajaran secara daring (online) melalui media Whatsapp, Zoom, Cloud Meeting, dan Short Message Servise (SMS). Jika diperlukan, pembelajaran juga dapat dilakukan secara luring, salah satunya yaitu guru mendatangi siswa langsung untuk memberikan motivasi belajar kepada siswa. Namun, hal tersebut berimplikasi terhadap sistem pembelajaran yang kurang efektif dan efisien karena tidak memadainya waktu dan juga besarnya biaya yang dikeluarkan, sehingga kebijakan tersebut masih belum optimal dilaksanakan. Berdasarkan beberapa metode pembelajaran yang digunakan pada masa pandemi Covid-19 ini diperoleh hasil bahwa metode pembelajaran yang paling efektif adalah menggunakan metode daring (online) melalui media Zoom dan Cloud Meeting. Sehingga dapat disimpulkan bahwa metode ini merupakan metode yang efektif dan bisa diterapkan di SMAN 1 Empang selama masa pandemi.
\end{abstract}

\section{PENDAHULUAN}

Coronavirus Disease 2019 atau yang sering disapa dengan nama Covid-19 merupakan virus jenis baru yang menyebabkan gangguan pada sistem pernafasan, pneumonia akut, bahkan bisa mengakibatkan kematian. Hingga saat ini, Covid-19 telah menyebar ke lebih dari 100 negara di dunia, termasuk juga Indonesia. Data kasus Covid-19 di Indonesia menunjukan bahwa terdapat 17.514 kasus yang terkonfirmasi, menyebabkan 1.148 kematian atau sama dengan $6,6 \%$ dari kasus terkonfirmasi ${ }^{1}$.
Pandemi Covid-19 menjadi kekhawatiran karena besarnya resiko yang mengancam banyak sektor, seperti sektor ekonomi, sosial, termasuk juga pendidikan. Salah satu yang paling dirasakan adalah dampak terhadap peserta didik di instansi penyelenggara pelayanan pendidikan, yaitu sekolah di semua tingkatan, lembaga pendidikan non formal hingga perguruan tinggi. Sebagaimana United Nations Educational, Scientific and Cultural Organization (UNESCO) mencatat, bahwa "Covid-19 berdampak pada pendidikan sekitar 290,5 juta pelajar di seluruh dunia" ${ }^{3}$. Lebih lanjut dikatakan oleh Direktur Jenderal 
UNESCO, Audrey Azoulay, bahwa "skala global dan kecepatan gangguan pendidikan saat ini tidak tertandingi dan jika diperpanjang, dapat mengancam hak atas pendidikan" 4 .

Beberapa tindakan pencegahan dan mitigasi yang efektif atas Covid-19 telah dilakukan di Indonesia, diantaranya adalah memberlakukan kegiatan bekerja dari rumah (work from home) diikuti dengan penyesuaian sistem kerja. Karena itu, semua pelayanan publik terkait ruang lingkup barang, jasa, maupun administrasi akan dilakukan secara daring (online) atau jika terdapat pelayanan manual harus mengimplementasikan mengukur suhu pengguna layanan, penyediaan tempat cuci tangan atau handsanitizer dan menjaga jarak. Hal ini juga berlaku pada sektor pendidikan, yaitu menonaktifkan kegiatan belajar mengajar di sekolah guna melakukan sterilisasi dan karantina mandiri terhadap pendidik/guru maupun peserta didik, sehingga berdampak pada mpenggantian kegiatan pembelajaran dilakukan secara daring (online) bahkan pada akhirnya ikut menghapus Ujian Nasional.

SMA Negeri 1 Empang merupakan salah satu sekolah menegah atas di Kabupaten Sumbawa yang telah menerapkan inovasi pembelajaran berbasis teknologi digital selama masa pandemi Covid-19. Pihak sekolah, khususnya kepala sekolah mengambil beberapa kebijakan yang telah disesuaikan dengan Surat Edaran Sekretaris Jenderal Kementerian Pendidikan dan Kebudayaan Nomor 15 Tahun 2020 tentang Pedoman Penyelenggaraan Belajar dari Rumah dalam Masa Darurat Penyebaran Coronavirus Disease (Covid19), sebagaimana telah diuraikan dalam Panduan Pembelajaran Jarak Jauh (PJJ) yang disusun oleh Kementerian Pendidikan dan Kebudayaan.

Salah satu kebijakan tersebut adalah dengan menutup sementara sekolah dan mengganti kegiatan pembelajaran secara daring (online) di samping juga menetapkan sistem luring (luar jaringan) untuk beberapa keadaan. Namun inovasi yang berjalan selama masa pandemi Covid-19 ini dirasa masih menimbulkan beberapa masalah, sebab terjadinya perubahan dalam proses pembelajaran tentu akan menimbulkan beberapa tantangan dan hambatan dalam penerapannya.

Pihak sekolah, khususnya pendidik/pengajar terlebih kepala sekolah atau pemimpin sekolah diharapkan mengetahui dan dapat menerapkan inovasi tertentu agar dapat mengembangkan proses pembelajaran yang berkualitas, sekalipun terdapat tantangan dan hambatan yang menyertainya. Adanya perubahan dalam pendidikan khususnya dalam hal kegiatan pembelajaran karena hal itu merupakan suatu hal yang memang sudah sewajarnya untuk dihadapi, terlebih pada masa pandemi Covid-19 ini, namun perlu dengan dasar pemikiran yang kuat, sehingga sebuah perubahan akan mengarah pada yang lebih baik dari sebelumnya. Artinya, inovasi yang memberikan perubahan ke arah yang lebih baik itu perlu dipikirkan secara mendalam. Sebagaimana inovasi pendidikan dalam hal inovasi pembelajaran diadakan untuk membantu pedidik/guru dan peserta didik dalam menata dan mengorganisasikan proses pembelajaran yang berkualitas sehingga tercapai tujuan belajar. Oleh karena itu, sekiranya penting untuk melakukan penelitian secara deskriptif kualitatif terhadap inovasi pembelajaran pada masa pandemi Covid-19, yang mana dalam penelitian ini akan dikhususkan dalam lingkup SMA Negeri 1 Empang guna memberi deskripsi sederhana tentang apa inovasi pembelajaran yang efektif dan efisien pada masa pandemi Covid-19.

\section{METODE}

Penelitian ini menggunakan analisis deskriptif, tidak ada hipotesis yang diuji. Sampel yang digunakan adalah 200 orang siswa yang menggunakan media pembelajaran daring yang diminta oleh staff pegajar. Karena penelitian ini juga merupakan penelitian kualitatif, maka peneliti akan berperan sebagai instrumen pertama dan utama dalam pengumpulan data. Data hasil nilai interaksi siswa menggunakan berbagai media daring yang ditentukan dianalisis menggunakan program excel 2010 untuk melihat media pembelajaran online yang paling efektif dimasa pandemi Covid-19.

\section{HASIL}

Berdasarkan beberapa metode yang telah digunakan dalam proses pembelajaran pada masa pandemi Covid-19 di SMAN 1 Empang diperoleh grafik sebagai berikut:

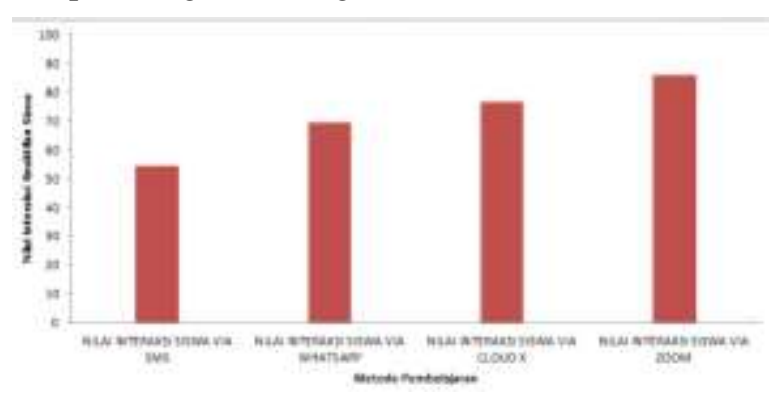

Grafik 1. Data interaksi setiap siswa dengan menggunakan meddia pembelajaran online 


\section{Pengaruh Covid-19 terhadap Bidang Pendidikan di SMA N 1 Empang}

Salah satu kebijakan pendidikan Pemerintah Indonesia adalah meningkatkan kualitas dan relevansi pendidikan dengan menerapkan standar nasional pendidikan sebagai acuan dan rambu-rambu hukum untuk meningkatkan mutu berbagai aspek pendidikan nasional termasuk mutu pendidikan pendidik/guru maupun mutu sarana dan prasarana pendidikan. Sebagaimana dirumuskan dalam Pasal 3 Undang-Undang Nomor 20 Tahun 2003 tetang Sistem Pendidikan $\mathrm{Nasional}^{5}$, bahwa pendidikan nasional berfungsi mengembangkan kemampuan dan membentuk watak serta peradaban bangsa yang bermartabat dalam rangka mencerdaskan kehidupan bangsa, bertujuan untuk berkembangnya potensi peserta didik agar menjadi manusia yang beriman dan bertakwa kepada Tuhan Yang Maha Esa, berakhlak mulia, sehat, berilmu, cakap, kreatif, mandiri, dan menjadi warga negara yang demokratis serta bertanggung jawab.

Secara umum, pendidikan merupakan suatu proses transfer ilmu yang dilakukan melalui tiga cara yaitu lisan, tulisan dan perbuatan. Pendidikan merupakan dasar seseorang untuk bisa mengembangkan dirinya menjadi seorang manusia seutuhnya. Artinya, sasaran pendidikan adalah manusia. Maksud diadakannya suatu pendidikan adalah untuk membantu peserta didik menumbuh kembangkan potensi-potensi kemanusiaannya. Potensi kemanusiaan ini merupakahn benih kemungkinan untuk menjadi manusia. Karenanya, tugas mendidik hanya mungkin dilakukan dengan benar dan tepat tujuan, apabila pendidik/guru memiliki gambaran yang jelas mengenai siapa manusia itu sebenarnya.

berinovasi serta kemampuan yang menunjang lainnya, maka diperlukan suatu usaha yang terus menerus ke arah lebih baik. Salah satunya adalah dengan menciptakan inovasi pendidikan yang dapat meningkatkan kemampuan pendidik/guru dan peserta didik.

Pendidikan merupakan salah satu faktor yang sangat penting bagi seseorang untuk meningkatkan kecerdasan, keterampilan, mengembangkan potensi diri dan dapat membentuk pribadi yang bertanggung jawab, cerdas dan kreatif. Namun, dengan pesatnya perkembangan lingkungan lokal, regional, dan internasional saat ini berimplikasi terhadap pengeloaan penyelenggaraan pendidikan pada setiap jenjang pendidikan yang ada.
Perkembangan ini berkaitan dengan kebutuhan untuk memenuhi tuntutan meningkatkan mutu pendidikan. Sebagaiamana oleh Departemen Pendidikan Nasional sendiri, terdapat 3 hal yang menjadi rencana strategis pembangunan pendidikan nasional yang akan tetap mendesak dan relevan dalam penyelenggaraan pendidikan nasional hingga pada waktu yang akan datang. Pertama, upaya peningkatan mutu pendidikan; kedua, relevansi yang tinggi dalam penyelenggaraan pendidikan; dan ketiga, tata kelola pendidikan yang kuat. ${ }^{6}$

Mutu pendidikan merupakan salah satu permasalahan yang dihadapi dunia pendidikan. Berbagai upaya untuk mengatasi masalah mutu pendidikan ini telah dilakukan, diantaranya dengan pembaharuan pada kegiatan pembelajaran yang mana merupakan kegiatan paling penting dalam sistem pendidikan nasional. Terlebih jika diikuti dengan tantangan dan hambatan, seperti yang terjadi hingga saat ini di Indonesia masih dalam masa pendemi Covid-19, yang berpengaruh pada kegiatan pembelajaraan. Hal tersebut juga ikut dirasakan di Indonesia, yakni dampak yang paling dirasakan adalah peserta didik di instansi penyelenggaraan pelayanan pendidikan (sekolah di semua tingkatan), salah satunya terjadi pada SMAN 1 Empang, khususnya berpengaruh pada kegiatan pembelajaran di sekolah.

Berdasarkan hasil wawancara beberapa pihak sekolah dan pengamatan secara langsung di SMAN 1 Empang, bahwa semenjak Menteri Pendidikan dan Kebudayaan mengeluarkan Surat Edaran Nomor 3 Tahun 2020 tentang Pencegahan Covid-19 pada Satuan Pendidikan, diikuti dengan Surat Edaran Menteri Kesehatan Nomor HK.02.01/menkes/199/2020 dan Surat Edaran Sekretaris Jenderal Kementerian Pendidikan dan Kebudayaan Nomor 36603/A.A5/OT/2020, beberapa tindakan dilakukan di SMA N 1 Empang. Tindakan tersebut harus diambil untuk melakukan tindakan pencegahan dan mitigasi yang efektif atas Covid-19 yang telah menjadi pandemi global, termasuk juga demi tetap memenuhinya hak pendidikan bagi peserta didik SMA N 1 Empang dan menciptakan mutu pendidikan yang berkualitas selama masa Di antara tindakan yang diambil sebagai kebijakan di SMAN 1 Empang selama masa pandemi Covid19 tersebut didasarkan pada Panduan Penyelenggaraan Pembelajaran Jarak Jauh (PJJ) yang disusun oleh Direktorat Jenderal Guru dan Tenaga Pendidikan Kementerian Pendidikan dan Kebudayaan. Beberapa tindakan yang diambil tersebut mempengaruhi pelaksanaan pembelajaran di SMAN 1 Empang. Adanya himbauan agar melakukan physical distancing 
yaitu himbauan untuk menjaga jarak, menjauhi aktivitas dalam segala bentuk kerumunan, perkumpulan, dan menghindari adanya pertemuan yang melibatkan banyak orang, maka pihak sekolah SMAN 1 Empang dalam hal ini menonaktifkan segala bentuk kegiatan di sekolah (salah satunya pelaksanaan pembelajaran di sekolah) dan menggantinya dengan belajar dari rumah melalui pembelajaran jarak jauh daring dan/atau luring yang dilaksanakan dengan tetap memperhatikan protokol penanganan Covid-19 dan disesuaikan dengan pedoman penyelenggaraan belajar dari rumah ${ }^{9}$. Mengenai pembelajaran jarak jauh yang menggunakan sistem daring dan/atau luring tersebut diserahkan pada keputusan masing-masing pendidik/guru. Pendidik/guru diberikan kebebasan untuk memilih cara dan mengembangkan kreatifitasnya untuk melaksanakan pembelajaran, baik secara daring maupun luring, selama hal itu mampu memenuhi hak pendidikan bagi peserta didik.

Pembelajaran di SMAN 1 Empang dengan sistem dalam jaringan (daring) dilakukan secara online dengan memanfaatkan teknologi digital, seperti tatap muka virtual melalui video conference, teleconference (dalam hal ini: Zoom dan Cloud Meeting), dan/atau diskusi dalam group di media sosial (dalam hal ini: WhatsApp) atau aplikasi pesan (Short Message Service/SMS). Kegiatan sekolah yang dilakukan secara daring ini lebih diutamakan untuk pelaksanaan pembelajaran oleh pendidik/guru terhadap peserta didik. Tidak hanya sebagai media agar tetap dapat memberikan materi pelajaran kepada peserta didik, termasuk juga untuk melakukan diskusi bahkan memberikan tugas dan ulangan. Kemudian, untuk pembelajaran melalui sistem luar jaringan (luring) dapat saja digunakan oleh pendidik/guru, selama tindakan tersebut membantu memenuhi hak pendidikan peserta didik ataupun sebagai pengganti pembelajaran daring yang belum dapat dilakukan untuk beberapa peserta didik yang memeliki kendala, seperti kendala untuk mempersiapkan sarana prasarana yang memadai, ataupun untuk memeberikan motivasi belajar terhadap peserta didik dengan cara mengunjungi rumah peserta didik namun tetap dengan memperhatikan protokol penanganan Covid-19. Berdasarkan beberapa metode pembelajaran yang digunakan pada masa pandemi Covid-19 ini diperoleh hasil bahwa metode pembelajaran yang paling efektif adalah menggunakan metode daring (online) melalui media Zoom dan Cloud Meeting. Hal ini disebabkan karena dengan menggunakan kedua media tersebut bisa terjadi interaksi langsung antara peserta didik dengan pengajar dan bisa memicu peserta didik untuk lebih aktif memberikan

pertanyaan-pertanyaan dan melakukan diskusi terkait mata pelajaran yang sedang berlangsung. Sedangkan jika menggunakan media teks berupa whatsapp atau SMS, rata-rata peserta didik sedikit yang menanggapi dan memberikan diskusi interkatif sehingga dirasa metode ini kurang efektif.

\section{KESIMPULAN}

Berdasarkan penelitian yang telah dilakukan terkait Inovasi Sistem Pembelajaran Pada Masa Pandemi Covid-19 (Suatu Studi Deskriptif Kualitatif Di SMAN 1 Empang), di temukan beberapa metode pembelajaran yang bisa mendukung kegiatan belajar mengajar selama pandemi Covid-19 yaitu dengan metode daring (melalui media Whatsapp, Zoom, Cloud Meeting, dan Short Message Servise (SMS)) dan laring (dengan cara guru mendatangi siswa langsung untuk memberikan motivasi belajar kepada siswa). Berdasarkan beberapa metode pembelajaran yang digunakan pada masa pandemi Covid-19 ini diperoleh hasil bahwa metode pembelajaran yang paling efektif adalah menggunakan metode daring (online) melalui media Zoom dan Cloud Meeting. Sedangkan metode laring dirasa kurang efektif sebab berimplikasi terhadap sistem pembelajaran yang kurang efektif dan efisien karena tidak memadainya waktu dan juga besarnya biaya yang dikeluarkan, sehingga kebijakan tersebut masih belum optimal dilaksanakan.

\section{SARAN}

Diperlukan pengembangan pembelajaran daring yang lebih efektif lagi kedepannya. Selain itu, diperlukan peran serta semua pihak dalam menciptakan inovasi pembelajaran yang efektif dan efisien, yaitu dengan lebih melibatkan kepala sekolah sebagai pemimpin dan manager pengembangan pembelajaran daring di samping perlu dukungan dari pendidik/guru, orang tua, serta peserta didik, termasuk komite sekolah dan pengawas sekolah.

\section{DAFTAR PUSTAKA}

Berdasarkan Data yang dihimpun oleh Gugus Tugas Percepatan Penanganan Covid-19 Indonesia, terdapat 17.514 kasus Covid-19 terkonfirmasi, 12.237 diantaranya dalam perawatan, dan 1.148 kasus meninggal di samping 4.129 kasus sembuh. Dalam https://covid-19.go.id/peta-sebaran, Akses pada 17 Mei 2020

WHO mendefiisikan pandemic sebagai penyebaran penyakit baru ke seluruh dunia. Dalam 
https://m.cnindonesia.com/internasional/202003 12000124-134-482676/who-umumkan-viruscorona-sebagai-pandemi? Akses pada 16 Mei 2020

Giovani Dio Prasasti, "UNESCO: Penitupan Sekolah Akibat Covid-19 Berdampak pada 290 Juta Pelajar di Dunia", dalam https://m.liputan6.com/health/read/419527 5/unesco-penutupan-sekolah-akibat-covid19-berdampak-pada-290-juta-pelajar-didunia, Akses pada 16 Mei 2020

Ibid.,

Indonesia, Undang-Undang tentang Sistem Pendidikan Nasional, UU No. 20 Tahun 2003, LN No. 78 Tahun 2003, TLN No. 4301, Bab II, Pasal 3

H.A. Rusdiana, Konsep Inovasi Pendidikan, Cetakan Pertama (Bandung: Pustaka Setia, 2014), hlm 5

Berdasarkan data yang dihimpun oleh Gugus Tugas Percepatan Penanganan Covid-19 Indonesia, terdapat 17.514 kasus Covid-19 terkonfirmasi, 12.237 diantaranya dalam perawatan, dan 1.148 kasus meninggal di samping 4.129 kasus sembuh. Dalam https://covid-19.go.id/peta-sebaran, Akses pada 17 Mei 2020

Giovani Dio Prasasti, "UNESCO: Penitupan Sekolah Akibat Covid-19 Berdampak pada 290 Juta Pelajar di Dunia", dalam https://m.liputan6.com/health/read/419527 5/unesco-penutupan-sekolah-akibat-covid19-berdampak-pada-290-juta-pelajar-didunia, Akses pada 16 Mei 2020

Lihat Surat Edaran Setjen Kemendikbud Nomor 15 Tahun 2020 tentang Pedoman Penyelenggaraan Belajar dari Rumah dalam Masa Darurat Penyebaran Corona Virus Disease (Covid-19). 